\title{
Ecological Solid Waste Management Program of Elementary Schools in Agusan del Norte Division: Success Stories, Challenges and Prospects
}

\author{
Antonina A. Prisco*, Ariel U. Cubillas, PhD** \\ antonina.prisco@deped.gov.ph, aucubillas@carsu.edu.ph \\ DepEd - Division of Agusan del Norte* \\ Caraga State University, Ampayon, Butuan City** \\ DOI: 10.29322/IJSRP.12.01.2022.p12144 \\ http://dx.doi.org/10.29322/IJSRP.12.01.2022.p12144
}

\begin{abstract}
The main goal of the study is to ascertain level of Ecological Solid Waste Management Program awareness, implementation and performance of the public elementary schools, discover their success stories and unveil the challenges and prospects in the implementation of ESWM. It involved the stakeholders who have maximum participation in the implementation of the program which include the school head, school coordinator, district coordinator, district supervisor, teacher, student leader, barangay official, PTA officer and partner. The study used a simple random sampling through lottery technique. There were 300 stakeholders from selected schools of Agusan del Norte Division who participated in the study. As revealed in the study, there were several success stories and challenges encountered by the schools during their implementation of the program. Furthermore, it was also found out that schools implemented the prohibitions on ESWM under Section 48 of RA 9003 extensively and the school ESWM program is functioning well which implies that the stakeholders believe that the schools indeed had implemented the ESWM program and that they had observed well and adhered to the prohibitions of the mentioned Act and they had integrated the waste management concept to the schools' curricula pursuant to the Act.

Analysis of data showed that there is a significant relationship between the level of awareness and implementation to the performance of the schools in the implementation of the program. Based on the findings a guideline model was crafted with the primary goal to assist the schools in implementing the program in an efficient and sustainable way where partners in the different areas are involved and commitment from them are obtained.
\end{abstract}

Keywords: composting, ecological solid waste management, recycle, reduce, recycle materials, solid waste, waste segregation

\section{Introduction}

The by-products of most of people's activities, whether it is as an individual or as a group, at home, in the workplace, or in a community are wastes. Garbage particularly solid wastes can create significant health problems and a very unpleasant living environment if not disposed of safely and appropriately.

According to World Bank's report in 2016, the worlds' cities generated 2.01 billion tons of solid waste, amounting to a footprint of 0.74 kilograms per person per day. With rapid population growth and urbanization, annual waste generation is expected to increase by $70 \%$ from 2016 levels to 3.40 billion tons in 2050 (The World Bank, 2019)

British Plastics Federation (2021) cited that residents in developing countries, especially the urban poor, are more severely impacted by unsustainably managed waste. In low-income countries, over $90 \%$ of waste is often disposed of in unregulated dumps or openly burned. These practices create serious health, safety, and environmental consequences. Saxena et al. (2018) explained that poorly managed waste serves as a breeding ground for disease vectors, contributes to global climate change through methane generation, and can even promote urban violence.

Managing waste is essential for building sustainable and livable cities, but it remains a challenge for many developing countries and cities. Effective waste management is expensive, often comprising 20\%-50\% of municipal budgets. Operating this essential municipal service requires integrated systems that are efficient, sustainable, and socially supported (World Bank, 2016).

In the Philippines, the government enacted laws that served as a roadmap in the implementation of solid waste management. These laws are the Republic Act 9003 otherwise known as the "Ecological Solid Waste Management Act of 2000" and Republic Act No. 9512 otherwise known as "Environmental Awareness Education Act of 2008." RA No. 9512 mandated schools at all levels, whether public or private to integrate environmental education in the school curricula.

With the passage of the above-cited laws, the Provincial Government of Agusan del Norte thru the Environment and Natural Resources Division (ENRD) implemented the Ecological Solid Waste Management Program. The ENRD partnered with the Department of Education - Division of Agusan del Norte in the Annual Search for Best Implementing Schools on Ecological Solid Waste Management Program. This search started on SY 2011-2012 for public elementary schools only. Then, on SY 2017-2018, it added another category for public secondary schools.

Several initiatives were proposed by different government and private agencies to strengthen the solid waste management implementation, observations and data show that the program still needs intensification to leverage its implementation. Parocha et al. (2015) recommended that schools should design school-based SWM Program that builds positive attitudes, knowledge and skills in segregation, continuously educates pupils to build their attitude, develops a culture that gives importance to cleanliness of the surroundings and a culture that sees segregation as a normal routine, implements projects that utilize teaching and learning strategies that integrate meaningful community service with instruction and reflection to enrich the learning experiences, creates and imposes policies that will lead to decreased residual wastes, and to integrate waste management with composting in the grade school curriculum. This is the very reason why this study is conceptualized.

In similar vein, Paghasian (2017) also proposed that the school administration should have information drive/campaign on Solid Waste Management every General Orientation Programs, Convocation Programs and in Homeroom classes to ensure full 
awareness on the wise disposal of garbage. Tornillo (2018) also asserted that to strengthen the implementation of SWM in schools, proper information dissemination not only to the students and teachers but also to the parents must be done.

\section{The Objectives of the Study}

The main goal of the study is to explore the level of awareness, implementation, and performance of the public elementary schools in Ecological Solid Waste Management Program. Specifically, it aims to determine the level of awareness, implementation and performance of the schools in terms of (1) Implementing Guidelines on the Integration of Ecological Solid Waste Management under the National Greening Program; (2) Enactment of the DepEd of Section 48 Prohibitions of the Republic Act No. 9003 known as "Ecological Solid Waste Management Act of 2000"; and (3) Integration of the schools on curricula waste management concept pursuant to RA 9512. Entitled "An act to Promote Environmental Education and other Purposes". It also aims to correlate the level of awareness and the level of implementation on ESWMP and associate the level of performance with the level implementation as well as the level of awareness on ESWMP. This study also narrates success stories showcasing the best practices/initiatives of the public elementary schools in the implementation of ESWMP and unveils the challenges encountered by the public elementary schools in the implementation of ESWMP. It also proposes localized guideline model which would help address the deficiencies in the implementation of Ecological Solid Waste Management Program in the public elementary schools

\section{Framework of the Study}

This study is anchored on the Theory of Planned Behavior which was developed by Icek Ajzen (1991). The Theory of Planned Behavior or TPB, an extension of the Theory of Reasoned Action (TRA; Ajzen \& Fishbein, 1980), has been very widely applied and has demonstrated empirical strength in predicting individuals' intentions and behavior (Armitage \& Conner, 2001; Kaiser et al., 2005; Kollmuss \& Agyeman, 2002; Oreg \& Katz-Gerro, 2006; Cabaniss, 2014). It has mostly been applied in the public health field toward applications such as smoking cessation, sexual behavior, and nutrition (Hardeman et al., 2002; Cabaniss, 2014). In general, it was also considered as a general model to predict and explain behavior across a wide range of different types of behaviors.

The TPB expand on the TRA by including perceived behavioral control (PBC), which is a reflection of people's beliefs or "confidence in their ability to perform" a certain action (Ajzen, et al. 1986; Strydom, 2018), as well as an indication of the "available resources and opportunities". The perceived behavior control has an additional effect on people's intention to act, which is independent of either attitude or subjective norm (Ajzen, et al. 1986; Strydom, 2018). Apart from the intention to act, the executing of a behavior is also dependent on a person's

perception of the ability to perform the specific behavior-how easy or difficult it is to perform the specific action. Thus, PBC exerts pressure on the intention to behave, but also independently on the behavior itself (Ajzen, 1985; Strydom, 2018).

To make comparison with the other research endeavors on the similar topic of interest done in the developing countries, and anchoring on the significant viewpoints in TPB, this particular theory is also employed in this study to assess the level of awareness, implementation, and performance of the existing ecological solid waste management program and which will hopefully explain and helps understand the participants' behavior in practicing solid waste management in schools and/or their locality.

\section{Methodology}

The design used in the study is a mixed-method design. In particular, the descriptive-correlational method was applied. It is descriptive because it illustrated the participants' level of awareness, implementation, and performance on the ESWMP in their respective schools and it is also correlational since it involved the testing whether the relationship between the performance of the ESWMP and the implementation of its components exist or not. Moreover, it also tested whether the performance of the program significantly correlated with the level of awareness and the level of implementation. For the qualitative part, interview, focus group discussions (FGDs), triangulation, and the use of a camera for picture-taking were conducted to determine the success stories and challenges encountered in the implementation of the program. The statistical tools used to facilitate the interpretation of the data collected were the Frequency Counts and Percentages, Weighted Mean and Pearson Product Moment Correlation.

\section{Results and Discussion}

\section{The Level of Awareness of the Stakeholders on Ecological Solid Waste Management Program}

1.1 Implementing Guidelines on the Integration of Ecological Solid Waste Management under the National Greening Program As shown in the table, indicator number one (1) which states that DepEd undertakes DepEd Order No. 5, series 2014 on the implementing guidelines on the integration of Solid Waste Management Program under the National Greening Program (NGP garnered the highest mean of 4.69 or very satisfactory. This suggests that the stakeholders are very familiar with the issuance of the said DepEd Order. On the other hand, indicator number six (6) that states that DepEd charges the expenses incur to the regular Maintenance and Other Operating Expenses (MOOE), Special Education Fund (SEF), canteen proceeds, saving or donations, and shall become part of the regular budget of the school in the succeeding fiscal year obtained the lowest mean of 4.36 or satisfactory which means that the stakeholders are familiar with it.

The overall weighted mean on the level of awareness of the stakeholders in the ESWMP implementation is 4.56 or very satisfactory which means that the stakeholders are very familiar with the provision and which also indicates that they are very wellaware of the implementing guidelines on the integration of Ecological Solid Waste Management (ESWMP) under the National Greening Program. This also implies that the stakeholders' awareness on ecological solid waste management program in terms of implementing guidelines on the integration of ESWMP under the National Greening Program is in a very respectable level.

\section{Table 1}

Mean Distribution of the level of awareness of the stakeholders on ecological solid waste management program in terms of implementing guidelines on the integration of Ecological Solid Waste Management under the National Greening Program

\begin{tabular}{|c|c|c|c|c|}
\hline & \multirow{2}{*}{ Indicators } & \multicolumn{2}{|c|}{ Level of Awareness } & \multirow{2}{*}{ Interpretation } \\
\hline & & Mean & Description & \\
\hline 1 & $\begin{array}{l}\text { DepEd undertakes DepEd Order No. 5, series } 2014 \text { on the implementing } \\
\text { guidelines on the integration of Solid Waste Management Program under the } \\
\text { National Greening Program (NGP). }\end{array}$ & 4.69 & $\begin{array}{l}\text { Very } \\
\text { Satisfactory }\end{array}$ & Provision is very familiar \\
\hline
\end{tabular}


$\overline{2}$ DepEd issues guidelines to concretize directions in the implementation of the NGP pursuant to Section 5.2 of Executive Order (EO) No. 26, Series 201 and DepEd Memo. No. 58, Series 2011 entitled "Creating the Task Force on National Greening Program.

3 The Division NGP coordinator, EPP, and TLE supervisors and school health personal provide technical assistance to the School NGP coordinator.

4 The school heads take the lead in the implementation of NGP by integrating NGP in their SIP other co-curricular activities to ensure sustainability of the program

5 The school division personnel monitor the SWMB guidelines are enforced and complied by the school.

6 DepEd charges the expenses incur to the regular Maintenance and Other Operating Expenses (MOOE), Special Education Fund (SEF), canteen proceeds, saving or donations, and shall become part of the regular budget of the school in the succeeding fiscal year.

7 DepEd undertakes RA 9003 Solid Waste Management Act Implementing Rules and Regulations, Part 6, Rule 21, Section 2 to aggressively incorporate ecological waste management in the school system at all levels emphasizing on the involvement of school administrators, teaching and non-teaching staff, and students in school wide and nearby community waste management actions.

8 The school practices waste management principle such as minimization, specifically resource conservation and recovery, segregation at source, reduction, recycling, re-use and composting, in order to promote environmental awareness and action among the students.

9 DepEd undertakes curricula waste management concept pursuant to RA 9512. Entitled "An act to Promote Environmental Education and other Purposes".

Overall Weighted Mean

\section{$\begin{array}{ll}\text { 4.57 } & \text { Very } \\ \text { Satisfactory } & \text { Provision is very familiar }\end{array}$ \\ 4.47 Very $\quad$ Provision is very familiar \\ Satisfactory \\ 4.57 Very $\quad$ Provision is very familiar \\ 4.60 Very $\quad$ Provision is very familiar \\ 4.36 Satisfactory Provision is familiar}

$\begin{array}{ll}\text { 4.57 } & \text { Very } \\ \text { Satisfactory } & \text { Provision is very familiar }\end{array}$

4.59 Very $\quad$ Patisfactory $\quad$ Provision is very familiar

4.58 Very $\quad$ Provision is very familiar

$\begin{array}{ll}\text { 4.56 } & \text { Very } \\ \text { Satisfactory } & \text { Provision is very familiar }\end{array}$

Range of means: 1.00-1.49 (Never); 1.50-2.49 (Poor); 2.50-3.49 (Fair); 3.50-4.49 (Satisfactory); 4.50-5.00 (Very Satisfactory)

The result is affirmed by the DepEd through its issuance of DepEd Order No. 5, s. 2014 laid down the guidelines towards the implementation of Ecological Solid Waste Management Program under the National Greening Program. Moreover, in RA 9003, Section 56 emphasized that the national government, through the DECS and in coordination with concerned government agencies, NGOs and private institutions, shall strengthen the integration of environmental concerns in school curricula at all levels, with particular emphasis on the theory and practice of waste management principles like waste minimization, specifically resource conservation and recovery, segregation at source, reduction, recycling, re-use and composting, in order to promote environmental awareness and action among the citizenry.

Also, the Enhanced National Greening Program (E-NGP) gave priority on many activities that includes the promotion of public awareness as well as instill social and environmental consciousness on the value of forests and watersheds and among other things relative to rehabilitation of forest lands and maintenance and protection of existing forests (DENR, 2019).

\subsection{Enactment of the DepEd of Section 48 Prohibitions of the Republic Act No. 9003 known as "Ecological Solid Waste Management Act of 2000"}

As presented on the table, indicator number six (6) which states that the mixing of source-separated recyclable material with other solid waste in any vehicle, box, container or receptacle used in solid waste collection or disposal is one of the prohibited acts garnered the highest weighted mean of 4.39 which signifies that the participants are familiar with it.

Meanwhile, indicator number four (4) which indicates that open dumping, burying of biodegradable or non-biodegradable materials in flood-prone areas are prohibited obtained the lowest weighted mean of 3.80 which also signifies that the participants are familiar with it. In general, the overall weighted mean on the level of awareness of the stakeholders on the ecological solid waste management program in terms of enactment of the DepEd of Section 48 Prohibitions of the Republic Act No. 9003 known as "Ecological Solid Waste Management Act of 2000 is 3.98 or satisfactory which indicates that the provision is familiar to them.

The result reveals that the stakeholders are familiar with the prohibitions under RA 9003. However, they are not in full cognizant of the prohibition on open dumping, burying of biodegradable, or non-biodegradable materials in flood-prone areas. This situation may be due to the lack of information dissemination about this activity of the LGU itself, as well as DepEd for the dearth of initiatives on information dissemination. Thus, it is high time that schools should strengthen their information dissemination preferably soon after the CoVid-19 pandemic is over.

Anent the results above, Phan Hoang and Kato (2013) surveyed 247 students in DA Nang city whereby two elementary school students' knowledge of SWM were assessed. The results in February 2015 indicated that $96 \%$ of the student developed an absolute interest in SWM activities. The study also resulted in a change in student knowledge after environmental education for a year.

Table 2

Mean Distribution of the level of awareness of the stakeholders on ecological solid waste management program in terms of enactment of the DepEd of Section 48 Prohibitions of the Republic Act No. 9003 known as "Ecological Solid Waste Management Act of 2000"

\begin{tabular}{|c|c|c|c|c|}
\hline & \multirow{2}{*}{ Indicators } & \multicolumn{2}{|c|}{ Level of Awareness } & \multirow{2}{*}{ Interpretation } \\
\hline & & Mean & Description & \\
\hline 1 & $\begin{array}{l}\text { Littering, throwing, dumping of waste matters in public places, such } \\
\text { as roads, sidewalks, canals, esteros or parks, and establishment, or } \\
\text { causing or permitting the same; }\end{array}$ & 3.97 & Satisfactory & Provision is familiar \\
\hline 2 & The open burning of solid waste. & 3.89 & Satisfactory & Provision is familiar \\
\hline 3 & $\begin{array}{l}\text { Causing or permitting the collection of non-segregated or unsorted } \\
\text { waste; }\end{array}$ & 3.93 & Satisfactory & Provision is familiar \\
\hline 4 & $\begin{array}{l}\text { Open dumping, burying of biodegradable or non-biodegradable } \\
\text { materials in flood-prone areas; }\end{array}$ & 3.80 & Satisfactory & Provision is familiar \\
\hline 5 & $\begin{array}{l}\text { Unauthorized removal of recyclable material intended for collection } \\
\text { by authorized persons; }\end{array}$ & 3.89 & Satisfactory & Provision is familiar \\
\hline 6 & $\begin{array}{l}\text { The mixing of source-separated recyclable material with other solid } \\
\text { waste in any vehicle, box, container or receptacle used in solid } \\
\text { waste collection or disposal; }\end{array}$ & 4.39 & Satisfactory & Provision is familiar \\
\hline & Overall Weighted Mean & 3.98 & Satisfactory & Provision is familiar \\
\hline
\end{tabular}

This publication is licensed under Creative Commons Attribution CC BY. 
Range of means: 1.00-1.49 (Never); 1.50-2.49 (Poor); 2.50-3.49 (Fair); 3.50-4.49 (Satisfactory); 4.50-5.00 (Very Satisfactory)

In addition, Licy et al. (2013) conducted a survey to assess waste management practice information among school children in Kerala using a well-structured questionnaire. Three hundred students were randomly selected for the studies. The result showed that high school students are more aware of waste when compared to high secondary students. The study revealed the need for massive awareness of waste practice from the beginning of school as well as the urgent need to rectify the knowledge and practice gap in waste management.

\subsection{Integration of the schools on curricula waste management concept pursuant to RA 9512. Entitled "An act to Promote} Environmental Education and other Purposes"

As observed in the table, indicator number nine (9) which states that schools appoint a school representative to become a regular member of the Barangay Solid Waste Management Committee of its host barangay as mandated in R.A. 9003 garnered the highest weighted mean of 4.53 which signifies that the stakeholders are aware about the provisions.

Table 3

Mean Distribution of the level of awareness of the stakeholders on ecological solid waste management program in terms of integration of the schools' curricula on waste management concept pursuant to RA 9512, entitled "An act to Promote Environmental Education and other Purposes."

\begin{tabular}{|c|c|c|c|c|}
\hline & \multirow{2}{*}{ Indicators } & \multicolumn{2}{|c|}{ Level of Awareness } & \multirow{2}{*}{ Interpretation } \\
\hline & & Mean & Description & \\
\hline 1 & Enforce prohibition of littering and burning of wastes. & 4.51 & Very Satisfactory & Provision is very familiar \\
\hline 2 & $\begin{array}{l}\text { Institutionalize waste minimization measures and promote avoidance of } \\
\text { single-use disposable products and packaging materials such as plastic } \\
\text { bags, straws, spoons, forks and disposable laminated paper cups and } \\
\text { plates. }\end{array}$ & 4.52 & Very Satisfactory & Provision is very familiar \\
\hline 3 & Encourage students to bring trash-free "baon" to school. & 4.19 & Satisfactory & Provision is familiar \\
\hline 4 & $\begin{array}{l}\text { Establish aerobic and anaerobic system for processing biodegradable } \\
\text { wastes. }\end{array}$ & 4.34 & Satisfactory & Provision is familiar \\
\hline 5 & $\begin{array}{l}\text { Use recyclables (plastics, bottles, etc.) as seed beds in the nursery or } \\
\text { garden. }\end{array}$ & 4.46 & Satisfactory & Provision is familiar \\
\hline 6 & $\begin{array}{l}\text { Implement in the canteen the use of reusable food containers and avoid } \\
\text { selling processed food wrapped in non-recyclable packaging, e.g. candies, } \\
\text { cookies, biscuits, etc. }\end{array}$ & 4.39 & Satisfactory & Provision is familiar \\
\hline 7 & $\begin{array}{l}\text { Avoid consumables, such as bottled water, coffee, and sugar and creamier } \\
\text { in sachets during meetings and events. Refillable dispensers should be } \\
\text { used instead. Food caterers should use reusable food containers. }\end{array}$ & 4.42 & Satisfactory & Provision is familiar \\
\hline \multirow[t]{4}{*}{8} & $\begin{array}{l}\text { Designate or assign an area as Material Recovery Facility that serve as area } \\
\text { for: }\end{array}$ & & & \\
\hline & $\begin{array}{l}\text { a. discards that can still be repaired and reused, such as tables, desks and } \\
\text { shelves; }\end{array}$ & 4.42 & Satisfactory & Provision is familiar \\
\hline & $\begin{array}{l}\text { b. different recyclables, such as bottles, cans and plastics containers, which } \\
\text { will be collected by a designated junkshop partner }\end{array}$ & 4.34 & Satisfactory & Provision is familiar \\
\hline & $\begin{array}{l}\text { c. temporary storage area for the school's residuals (non-recyclable and } \\
\text { non-biodegradable discards) such as used rags, rubber. }\end{array}$ & 4.36 & Satisfactory & Provision is familiar \\
\hline \multirow[t]{2}{*}{9} & $\begin{array}{l}\text { Appoint a school representative to become a regular member of the } \\
\text { Barangay Solid Waste Management Committee of its host barangay as } \\
\text { mandated in R.A. } 9003 \text {. }\end{array}$ & 4.53 & Very Satisfactory & Provision is very familiar \\
\hline & Overall Weighted Mean & 4.41 & Satisfactory & Provision is familiar \\
\hline
\end{tabular}

On the other hand, indicator number three (3) which indicates that the schools encourage students to bring trash-free "baon" to school garnered the lowest weighted mean of 4.19 which also signifies that the participants are familiar with the provision. The overall weighted mean is 4.41 or satisfactory which signifies that the level of awareness of the participants in the integration of ESWMP in the schools' curricula per RA 9512 is in a respectable level.

The result reveals that the stakeholders are very well-informed of the appointment of school representative to the Barangay ESWM Board. Mostly, school representatives to this Barangay ESWM Board are the school principals or their School ESWM Coordinators. Through their attendance to the meetings, they can share what the schools are doing with regards to ESWM activities and likewise gain support from the BLGU partners. However, encouraging students to bring "trash-free" baon is less emphasized in schools. This may be due to the unavailability of such items at home and purchasing such items may not be much affordable for the parents and most of the students do not observe such policy is the schools unless there will be corresponding punishments or consequences imposed.

In view of the results above, Republic Act No. 9512, An Act to Promote Environmental Awareness through Environmental Education and for other Purposes mandated the Department of Education (DepEd), as well other government-line agencies to integrate environmental education in its school curricula at all levels, whether public or private, including in barangay daycare, preschool, nonformal, technical vocational, professional level, indigenous learning and out-of-school youth courses or programs. It mainly focused on environmental concepts and principles, environmental laws, the state of international and local environment, local environmental best practices, the threats of environmental degradation and its impact on human well-being, the responsibility of the citizenry to the environment and the value of conservation, protection and rehabilitation of natural resources and the environment in the context of sustainable development (Official Gazette, 2012).

In relation to the Act above, DepEd Order No. 5 s. 2014, directed all public elementary and secondary schools nationwide to integrate the ecological waste management and tree growing and caring as key components to attain the goals of the department on poverty reduction, food security, biodiversity conservation and climate change mitigation and adaptation. The schools also, in accordance to NGP, must practice waste management principles such as minimization, segregation at source, reduction, recycling, the re-use and composting, and many more.

\section{The Level of Implementation of the Stakeholders on Ecological Solid Waste Management Program}

2.1 Implementing Guidelines on the Integration of Ecological Solid Waste Management under the National Greening Program 
As gleaned on the table, indicator number one (1) which states that DepEd undertakes DepEd Order No. 5, series 2014 on the implementing guidelines on the integration of Solid Waste Management Program under the National Greening Program (NGP) obtained the highest weighted mean of 4.54 that is described as very satisfactory which signifies that the implementation of the said provision is very extensive and functioning very well.

Table 4

Mean Distribution of the extent of implementation of the schools on ecological solid waste management program in terms of implementing guidelines on the integration of Ecological Solid Waste Management under the National Greening Program

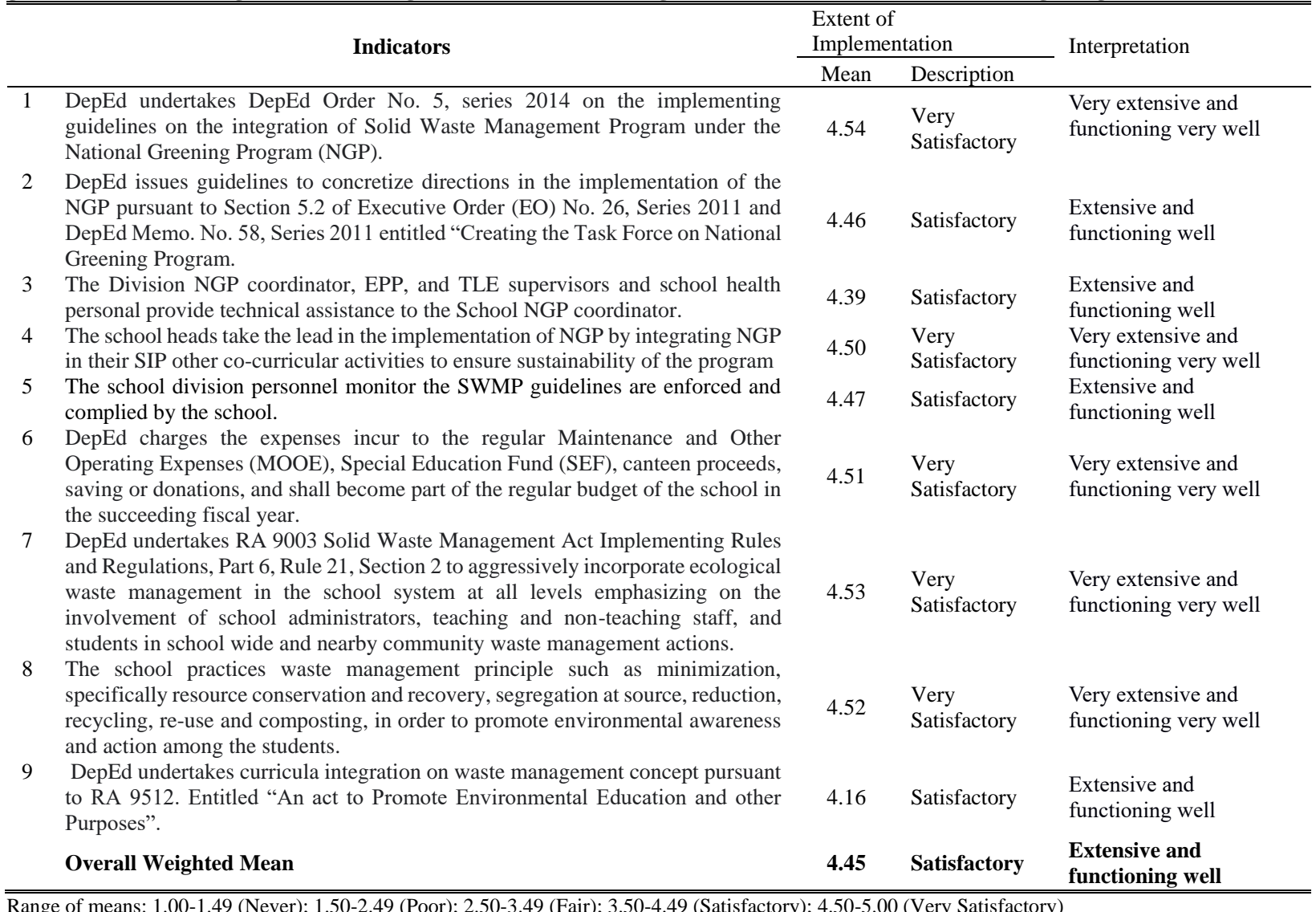

On the other hand, indicator number nine (9) which states that DepEd undertakes curricula integration on waste management concept pursuant to RA 9512, entitled "An act to Promote Environmental Education and other Purposes" garnered the lowest weighted mean of 4.16 that is described as satisfactory. This signifies that the implementation of the guideline is extensive and functioning well. Generally, the overall weighted mean on the level of implementation of the schools on ESWM as rated by the participants is 4.45 or satisfactory.

The findings reveal that the schools have implemented the program extensively and the program is indeed functioning well. This suggests that the schools truly integrated the Solid Waste Management Program under the National Greening Program in their curriculum through the curricular and co-curricular activities that they have undertaken. However, the results also imply that less emphasis was given on the curricula integration as mandated under RA 9512. This is attributed to the selection of the most essential learning competencies as a response of DepEd to address the challenges posed by the pandemic. The MELCs focuses instruction to the most essential and indispensable competencies that the learners must acquire. Thus, the competencies that are relative to NGP are not much highlighted at this present situation.

Cognizant of the significant role of education in solid waste management, R.A. 9003 mandates Philippine learning institutions to integrate into their educational activities the awareness and practices of solid waste management for the environmental education of all members of the academic community. The introduction or integration of 21 waste management concepts and themes through environmental education in school at all levels is hoped to improve the understanding of the members of the academic community on proper waste management and more likely change their seemingly unfriendly waste management behavior and practices (Madrigal \& Oracion, 2018 as cited by Lalamonan, 2020).

\subsection{Enactment of the DepEd of Section 48 Prohibitions of the Republic Act No. 9003 known as "Ecological Solid Waste Management Act of 2000"}

As gleaned in the table, the schools have implemented well the indicator number five (5) which states that the prohibitions on unauthorized removal of recyclable material intended for collection by authorized persons got the weighted mean of 4.39 or satisfactory. On the other hand, indicator number three (3) which states that the prohibitions on causing or permitting the collection of non-segregated or unsorted waste garnered the lowest weighted mean of 3.89 or satisfactory which signifies extensive implementation and a wellfunctioning program.

Table 5

Mean Distribution of the extent of implementation of the schools on ecological solid waste management program in terms of enactment of the DepEd of Section 48 Prohibitions of the Republic Act No. 9003 known as "Ecological Solid Waste Management Act of 2000"

\begin{tabular}{|c|c|c|c|c|}
\hline & \multirow{2}{*}{ Indicators } & \multicolumn{2}{|c|}{ Extent of Implementation } & \multirow{2}{*}{ Interpretation } \\
\hline & & Mean & Description & \\
\hline 1 & $\begin{array}{l}\text { Littering, throwing, dumping of waste matters in public places, } \\
\text { such as roads, sidewalks, canals, esteros or parks, and } \\
\text { establishment, or causing or permitting the same; }\end{array}$ & 3.94 & Satisfactory & Extensive and functioning well \\
\hline 2 & The open burning of solid waste. & 3.96 & Satisfactory & Extensive and functioning well \\
\hline 3 & $\begin{array}{l}\text { Causing or permitting the collection of non-segregated or unsorted } \\
\text { waste; }\end{array}$ & 3.89 & Satisfactory & Extensive and functioning well \\
\hline
\end{tabular}


$\overline{4}$ Open dumping, burying of biodegradable or non-biodegradable

\subsection{7}

4.39

Unauthorized removal of recyclable material intended for collection by authorized persons;

6 The mixing of source-separated recyclable material with other solid waste in any vehicle, box, container or receptacle used in solid waste collection or disposal; Overall Weighted Mean

\section{Satisfactory Extensive and functioning well \\ Satisfactory Extensive and functioning well \\ Satisfactory Extensive and functioning well}

4.08

Satisfactory Extensive and functioning well

Range of means: 1.00-1.49 (Never); 1.50-2.49 (Poor); 2.50-3.49 (Fair); 3.50-4.49 (Satisfactory); 4.50-5.00 (Very Satisfactory)

In general, the overall weighted mean on the level of implementation of the schools on ecological solid waste management program in terms of enactment of the DepEd of Section 48 or Prohibitions of the Republic Act No. 9003 known as "Ecological Solid Waste Management Act of 2000" is 4.08 or satisfactory. This signifies that the school has implemented the prohibitions on ESWM under Section 48 of RA 9003 extensively and that the school ESWM program is functioning well. This also implies that the stakeholders believe that the schools indeed had implemented the ESWM program and that they had observed well and adhered to the prohibitions of the mentioned Act.

According to Tuncer el al., (2009) as cited by Bautista (2019), eeducation on the environment is considered the key to reducing environmental problems. Prevention of any kind of human damage to the environment can be realized by promoting responsible citizenship. As the world is faced with critical environmental problems, educational systems must produce environmentally literate citizens who care about the environment and who possessed sufficient knowledge about environmental issues. Therefore, if DepEd personnel particularly in the schools in partnership with other stakeholders will not grow tired in advocating to the general public the prohibitions under RA 9003, the schools can level up its implementation to a very respectable level.

\subsection{Integration of the schools on curricula waste management concept pursuant to RA 9512, entitled "An act to Promote}

\section{Environmental Education and other Purposes"}

As reflected in the table, the participants gave the highest weighted mean of 4.44 or satisfactory to indicator number one (1) which states that the schools enforce prohibition of littering and burning of wastes and indicator number nine (9) which states the appointment of a school representative to become a regular member of the Barangay Solid Waste Management Committee of its host barangay as mandated in R.A. 9003. Meanwhile, indicator number two (2) which states that the schools institutionalize waste minimization measures and promote avoidance of single-use disposable products and packaging materials such as plastic bags, straws, spoons, forks and disposable laminated paper cups and plates garnered the lowest weighted mean of 4.29 or satisfactory which signifies an extensive implementation of the schools and that the program is functioning well.

The results reveal that the schools' implementation of the ecological solid waste management program in terms of integration of waste management concept to the schools' curricula pursuant to RA 9512, entitled "An act to Promote Environmental Education and other purposes" are extensive and that the program is functioning well.

Table 6

Mean Distribution of the extent of implementation of the schools on ecological solid waste management program in terms of integration of waste management concept to the schools' curricula pursuant to RA 9512, entitled "An act to Promote Environmental Education and other Purposes."

\begin{tabular}{|c|c|c|c|c|}
\hline & \multirow{2}{*}{ Indicators } & \multicolumn{2}{|c|}{ Extent of Implementation } & \multirow{2}{*}{ Interpretation } \\
\hline & & Mean & Description & \\
\hline 1 & Enforce prohibition of littering and burning of wastes. & 4.44 & Satisfactory & Extensive and functioning well \\
\hline 2 & $\begin{array}{l}\text { Institutionalize waste minimization measures and promote avoidance of } \\
\text { single-use disposable products and packaging materials such as plastic } \\
\text { bags, straws, spoons, forks and disposable laminated paper cups and } \\
\text { plates. }\end{array}$ & 4.29 & Satisfactory & Extensive and functioning well \\
\hline 3 & Encourage students to bring trash-free "baon" to school. & 4.43 & Satisfactory & Extensive and functioning well \\
\hline 4 & $\begin{array}{l}\text { Establish aerobic and anaerobic system for processing biodegradable } \\
\text { wastes. }\end{array}$ & 4.30 & Satisfactory & Extensive and functioning well \\
\hline 5 & $\begin{array}{l}\text { Use recyclables (plastics, bottles, etc.) as seed beds in the nursery or } \\
\text { garden. }\end{array}$ & 4.41 & Satisfactory & Extensive and functioning well \\
\hline 6 & $\begin{array}{l}\text { Implement in the canteen the use of reusable food containers and avoid } \\
\text { selling processed food wrapped in non-recyclable packaging, e.g. candies, } \\
\text { cookies, biscuits, etc. }\end{array}$ & 4.41 & Satisfactory & Extensive and functioning well \\
\hline \multirow[t]{2}{*}{7} & $\begin{array}{l}\text { Avoid consumables, such as bottled water, coffee, and sugar and creamier } \\
\text { in sachets during meetings and events. Refillable dispensers should be } \\
\text { used instead. Food caterers should use reusable food containers. }\end{array}$ & 4.38 & Satisfactory & Extensive and functioning well \\
\hline & $\begin{array}{l}\text { Designate or assign an area as Material Recovery Facility that serve as area } \\
\text { for: }\end{array}$ & & & \\
\hline \multirow{3}{*}{8} & $\begin{array}{l}\text { a. discards that can still be repaired and reused, such as tables, desks and } \\
\text { shelves; }\end{array}$ & 4.39 & Satisfactory & Extensive and functioning well \\
\hline & $\begin{array}{l}\text { b. different recyclables, such as bottles, cans and plastics containers, which } \\
\text { will be collected by a designated junkshop partner }\end{array}$ & 4.37 & Satisfactory & Extensive and functioning well \\
\hline & $\begin{array}{l}\text { c. temporary storage area for the school's residuals (non-recyclable and } \\
\text { non-biodegradable discards) such as used rags, rubber. }\end{array}$ & 4.43 & Satisfactory & Extensive and functioning well \\
\hline \multirow[t]{2}{*}{9} & $\begin{array}{l}\text { Appoint a school representative to become a regular member of the } \\
\text { Barangay Solid Waste Management Committee of its host barangay as } \\
\text { mandated in R.A. } 9003 \text {. }\end{array}$ & 4.44 & Satisfactory & Extensive and functioning well \\
\hline & Overall Weighted Mean & 4.39 & Satisfactory & $\begin{array}{l}\text { Extensive and functioning } \\
\text { well }\end{array}$ \\
\hline
\end{tabular}

Generally, the overall weighted mean on the extent of implementation of the schools under the integration of waste management concept to the schools' curricula pursuant to RA 9512, An act to Promote Environmental Education and other Purposes is 4.39 or satisfactory. This manifests that the stakeholders believe that the schools had implemented the ESWM program and that they had integrated the waste management concept to the schools' curricula pursuant to the Act.

Section 3 of RA 9512 emphasized that DepEd and other relevant agencies, shall integrate environmental education in its school curricula at all levels, whether public or private, including the barangay daycare, preschool, non-formal, technical vocational, professional level, indigenous learning and out-of-school youth courses or programs. Environmental education should encompass 
environmental concepts and principles, environmental laws, the state of international and local environment, local environmental best practices, the threats of environmental degradation and its impact on human well-being, the responsibility of the citizenry to the environment and the value of conservation, protection and rehabilitation of natural resources and the environment in the context of sustainable development. It should cover both theoretical and practicum modules comprising of activities, projects, programs including, but not limited to, tree planting; waste minimization, segregation, recycling and composting; freshwater and marine conservation; forest management and conservation; relevant livelihood opportunities and economic benefits; and other such programs and undertakings to aid the implementation of the different environmental protection laws. The integration of environmental concepts to the schools' curricula is first mandated under RA 9003 and was also mentioned by Paghasian (2017) as cited by Bautista (2019).

\section{The Level of Performance of the Stakeholders on Ecological Solid Waste Management Program \\ 3.1 Environment-Related School Policy}

As viewed on the table, as for the performance of the schools in terms of environment-related aspects of the school policy, the participants gave the highest weighted mean of 4.66 or very satisfactory to indicator number $2 \mathrm{c}$ which states that the schools prepare ecological waste management program which includes person/s or committee/s assign to implement school ESWM program and projects and which is interpreted as that the activities were done four (4) to five (5) times in the last five (5) years. On the other hand, indicator 2a which states that the schools prepare ecological waste management program which includes the implementation of rules and regulations of the school's environmental policy garnered the lowest weighted mean of 4.45 or satisfactory which signifies that such activities were done thrice in the last five (5) years.

The overall weighted mean on the performance of the schools in terms of environment-related aspects of the school policy is 4.39 or satisfactory. This means that the schools done the environment-related aspects of school policy four (4) to five (5) times in the last five (5) years or almost yearly or annually.

The study of A study by Ikhlayel (2018), he reported that waste management is a complex sustainability issue that requires a clear vision and integrative approach in addressing its intrinsic association with many environmental and economic drives. According to him, to sustain SW or environmental issues in developing countries, formal education for sustainable development is essential at all levels of education, able to trigger a whole societal transformation. For better environmental sustainability or waste management sustainability education, teachers with the right knowledge, attitude, skills, and innovation, are required. Accordingly, this study reviewed how formal environmental education in schools can help sustain SWM toward cleaner production (CP) in low/middle-income countries.

Table 7

Mean Distribution of the level of performance of the schools in terms of Environment-Related Aspects of the School Policy

\begin{tabular}{|c|c|c|c|c|}
\hline & \multirow{2}{*}{ Indicators } & \multicolumn{2}{|c|}{ Level of Performance } & \multirow{2}{*}{ Interpretation } \\
\hline & & Mean & Description & \\
\hline 1 & $\begin{array}{l}\text { Issuance of environment policy/ies of the school is existing through } \\
\text { school memorandum or order. }\end{array}$ & 4.48 & Satisfactory & Done thrice in the last five (5) years \\
\hline 2 & $\begin{array}{l}\text { Prepare Ecological Waste Management Program which include the } \\
\text { following: } \\
\text { a. Implementing rules and regulations of the school's environmental } \\
\text { policy }\end{array}$ & 4.45 & Satisfactory & Done thrice in the last five (5) years \\
\hline & b. Action plan & 4.54 & $\begin{array}{l}\text { Very } \\
\text { Satisfactory }\end{array}$ & $\begin{array}{l}\text { Done four (4) to five ( } 5 \text { ) times in the } \\
\text { last } 5 \text { years }\end{array}$ \\
\hline & $\begin{array}{l}\text { c. Person/s or committee/s assign to implement school ESWM } \\
\text { program and projects. }\end{array}$ & 4.66 & $\begin{array}{l}\text { Very } \\
\text { Satisfactory }\end{array}$ & $\begin{array}{l}\text { Done four (4) to five (5) times in } \\
\text { the last five years }\end{array}$ \\
\hline \multirow[t]{2}{*}{3} & $\begin{array}{l}\text { Environmental policy of the school is communicated to its } \\
\text { constituents through symposia/seminars, distribution of } \\
\text { leaflets/flyers and posting in strategic areas. }\end{array}$ & 4.49 & Satisfactory & Done thrice in the last five (5) years \\
\hline & Overall Weighted Mean & 4.52 & $\begin{array}{c}\text { Very } \\
\text { Satisfactory }\end{array}$ & $\begin{array}{l}\text { Done four (4) to five (5) times in } \\
\text { the last } 5 \text { years }\end{array}$ \\
\hline
\end{tabular}

Range of means: 1.00-1.49 (Never); 1.50-2.49 (Poor); 2.50-3.49 (Fair); 3.50-4.49 (Satisfactory); 4.50-5.00 (Very Satisfactory

Also, in January 2014, a survey of 247 students was conducted in DA Nang city. Two elementary school students' knowledge of SWM were assessed. The results in February 2015 indicated that $96 \%$ of the student developed an absolute interest in SWM activities. The study also resulted in a change in student knowledge after environmental education for a year (Phan Hoang \&Ka to, 2016).

\subsection{ESWM School Operations and Presence of Environmental Programs}

As reflected on the table, indicator 4 got the highest weighted mean of 4.63 or very satisfactory and interpreted as that the ESWM School Operations and Presence of Environmental Programs were done in four (4) to five (5) times in five (5) years. Meanwhile, indicator 4 which is about the environmental awards and recognitions received the lowest mean of 4.25 or satisfactory or interpreted as that done thrice in the last five (5) years.

The overall weighted mean is 4.52 or very satisfactory. This is interpreted as that the schools in terms of ESWM school operations and presence of environmental programs had done the related activities in four (4) to five (5) times in five (5) years.

Table 8

Mean Distribution of the level of performance of the schools in terms of ESWM School Operations and Presence of Environmental Programs

\begin{tabular}{|c|c|c|c|c|}
\hline & \multirow{2}{*}{ Indicators } & \multicolumn{2}{|c|}{ Level of Performance } & \multirow{2}{*}{ Interpretation } \\
\hline & & Mean & Description & \\
\hline 1 & $\begin{array}{l}\text { Waste Management Program a. Waste segregation ( } 3 \text { or more } \\
\text { garbage bins with cover, proper and legible signage and properly } \\
\text { segregated wastes) }\end{array}$ & 4.56 & Very Satisfactory & $\begin{array}{l}\text { Done four (4) to five (5) } \\
\text { times in five (5) years }\end{array}$ \\
\hline 1 & $\begin{array}{l}\text { b. Establishment of Solid Waste Containment Area or Materials } \\
\text { Recovery Facility (MRF) }\end{array}$ & 4.55 & Very Satisfactory & $\begin{array}{l}\text { Done four (4) to five (5) } \\
\text { times in five (5) years }\end{array}$ \\
\hline 1 & $\begin{array}{l}\text { c. Recycling practices (use as students/pupils projects; classroom or } \\
\text { school project and record of sales) }\end{array}$ & 4.55 & Very Satisfactory & $\begin{array}{l}\text { Done four (4) to five (5) } \\
\text { times in five (5) years }\end{array}$ \\
\hline 1 & $\begin{array}{l}\text { d. Waste composting (presence of composting policy and utilization } \\
\text { of compost material to the Gulayan sa Paaralan (GPP) and } \\
\text { Beautification) }\end{array}$ & 4.45 & Satisfactory & $\begin{array}{l}\text { Done thrice in the last five } \\
\text { (5) years }\end{array}$ \\
\hline 2 & $\begin{array}{l}\text { Paper conservation projects (reuse or recycled used paper and } \\
\text { availability of paper conservation trays or containers }\end{array}$ & 4.52 & Very Satisfactory & $\begin{array}{l}\text { Done four (4) to five ( } 5) \\
\text { times in five (5) years }\end{array}$ \\
\hline 3 & Greening program (well-grown plants and trees) & 4.50 & $\begin{array}{c}\text { Very } \\
\text { Satisfactoryy }\end{array}$ & $\begin{array}{l}\text { Done four (4) to five ( } 5) \\
\text { times in five (5) years }\end{array}$ \\
\hline
\end{tabular}

This publication is licensed under Creative Commons Attribution CC BY. 


\begin{tabular}{|c|c|c|c|c|}
\hline & & \multirow[b]{2}{*}{4.63} & & \multirow[b]{2}{*}{$\begin{array}{l}\text { Done four (4) to five (5) } \\
\text { times in five (5) years }\end{array}$} \\
\hline & $\begin{array}{l}\text { Maintain school cleanliness (classrooms, library, offices, comfort } \\
\text { rooms, etc) }\end{array}$ & & $\begin{array}{c}\text { Very } \\
\text { Satisfactoryy }\end{array}$ & \\
\hline 5 & Environmental awards and recognitions received & 4.28 & Satisfactoryy & $\begin{array}{l}\text { Done thrice in the last five } \\
\text { (5) years }\end{array}$ \\
\hline & Overall Weighted Mean & 4.51 & $\begin{array}{c}\text { Very } \\
\text { Satisfactory }\end{array}$ & $\begin{array}{l}\text { Done four (4) to five (5) } \\
\text { times in five (5) years }\end{array}$ \\
\hline
\end{tabular}

In consonance to the results above, Permaul and Phipatanakul, (2018) posited that the school-based environmental interventions may offer benefit for health problem and has the potential to help many children with such health problems at once in a cost-effective manner. They noted that it is important that environmental health researchers continue to assess which interventions are most practical and result in the greatest measurable improvements.

Furthermore, United States Environmental Protection Agency (2021) proposed that the benefits of state environmental health programs for schools can be seen in decreased absenteeism among children and teachers, 7,27 stronger academic performance,9,28,29 and higher scores on standardized tests.30 Small investments to address critical environmental issues in schools can save schools money by avoiding costly cleanups and remediation related to poor indoor air quality, mold and mildew damage, mismanaged chemicals, and pest infestation. By implementing school environmental health programs, states can help schools significantly improve their environments, where children spend more time than any other place outside of their homes.

\subsection{Partnership and Linkages in Environmental Programs and Projects}

As gleaned in the table, as there are only two (2) indicators appeared in it, the highlight could be focused on the overall weighted mean which is 3.92 or satisfactory. This rating is interpreted as that in terms of partnership and linkages in environmental programs and projects, the schools had done them thrice in the last five (5) years.

\section{Table 9}

Mean Distribution of the level of performance of the schools in terms of Partnership and Linkages in Environmental Programs and Projects

\begin{tabular}{|c|c|c|c|c|}
\hline & \multirow{2}{*}{ Indicators } & \multicolumn{2}{|c|}{ Level of Performance } & \multirow{2}{*}{ Interpretation } \\
\hline & & Mean & Description & \\
\hline 1 & Collaborate with local and national government agencies and offices & 3.97 & Satisfactory & Done thrice in the last five (5) years \\
\hline \multirow[t]{2}{*}{2} & Team up with private sectors. & 3.87 & Satisfactory & Done thrice in the last five (5) years \\
\hline & Overall Weighted Mean & 3.92 & Satisfactory & $\begin{array}{l}\text { Done thrice in the last five (5) } \\
\text { year }\end{array}$ \\
\hline
\end{tabular}

The significance of partnerships and linkages in SWG agenda is emphasized in the study of Nelson (2017) as he explained that partnerships and coalitions can play a vital role in helping to overcome some of these obstacles. They will be particularly in addressing the following four imperatives. First is improving the impact of all business activities, to support growth that is more responsible, inclusive and sustainable. Second is increasing the level of new private sector investment and innovation in sustainable development. Third is achieving systemic transformation of markets to work better for people and the environment. Fourth and last is building mutual trust, accountability and a new social contract between business, governments and civil society.

Moreover, in terms of coming up with best decisions relative to ESW, Public Linkage, Dialogue, and Education Task Force (1997) stated that local, state, and federal governments; parents, teachers, and schools; environmental organizations; and business associations should form partnerships to coordinate educational programs focusing on sustainable development. Such coordination should reduce duplication of efforts, increase availability of resources, and enhance stakeholder's knowledge and ability to make the decisions that will help their communities thrive.

\section{Correlation Analysis between the Level of Awareness and the Level of Implementation ESWMP}

As observed on the table, the computed p-value is below the 0.05 level of significance set for analysis. Hence, the null hypothesis is rejected. This means that there is a significant relationship between level of awareness and the level of implementation ESWMP. High positive correlation indicates that there is a strong association between the school stakeholders' level of awareness and their level of implementation of the Ecological Solid Waste Management Program. This also further manifests that when the stakeholders are well aware of or well-informed about the ESWMP, their existing practice may be guided by such level of information.

Table 10

Correlation analysis between the level of awareness and the level of implementation ESWMP

\begin{tabular}{lcccc}
\hline \multicolumn{1}{c}{ Variables } & Mean & SD & R & Sig. (2 - Tailed) \\
\hline Level of Awareness & 4.3598 & .51817 & 0.000 \\
Level of Implementation & 4.3399 & .56079 & $0.790^{* * *}$ & \multirow{2}{*}{0.000 (2-tailed) }
\end{tabular}

*** Correlation is significant at the 0.05 level (2-tailed)

One interesting study conducted by Twumasi (2017) by which its results was contradicts the results above. The objective of the study was to find information about waste management practice within a community in Ghana. In the survey, 120 people were randomly selected to respond to a well-designed questionnaire. The results indicated that most people were aware of SWM but never put it into practice. People's attitudes toward a social commitment to waste participation were weak. Twumasi noticed that e-waste awareness was absent in the community and it was necessary to rectify the knowledge and practice gap

Another study with contradicting result is by Ifegbesan, Ogunyemi, Rampedi (2017) which was conducted to determine the practice of SWM in public secondary school. The results showed an overall positive level of awareness, attitude, and practices of teachers toward SWM, but the practice was better in some schools, when compared to others.

However, the two studies above were not in consonance with the results of the study of Varoglu, Temel, and Yilmaz (2018). The study focused on the environmental literacy, attitudes, awareness, and behavior studies and was conducted among 335 middle school students in Eskisehir. The results showed that students develop positive attitudes toward the environment through awareness. In addition, a positive environmental attitude leads to pro-environmental behavior and adaptation of environmentally-friendly products. In other words, the level of awareness may tend to increase the level of practice or implementation.

\section{Association between the Level of Performance and the Level of Awareness on ESWMP}


As gleaned in the table, all computed p-values are below the 0.05 are below the 0.05 level of significance set for analysis. Hence, the null hypothesis is rejected. This means that there is a significant relationship between the level of performance and the level of awareness in terms of Implementing Guidelines on the Integration of Ecological Solid Waste Management under the National Greening Program, Enactment of the DepEd of Section 48 Prohibitions of the Republic Act No. 9003 known as "Ecological Solid Waste Management Act of 2000", and the Integration of the schools on curricula waste management concept pursuant to RA 9512. Entitled

"An act to Promote Environmental Education and other Purposes."

Table 11

Correlation analysis between the level of performance and the level of awareness

\begin{tabular}{|c|c|c|c|c|c|}
\hline Variables & Mean & SD & $\mathbf{R}$ & Sig. (2 - Tailed) & ** Correlation is \\
\hline $\begin{array}{l}\text { Level of Performance } \\
\text { vs. } \\
\text { Level of Awareness }\end{array}$ & 4.4240 & .61148 & & & $\begin{array}{l}\text { significant at the } \\
0.05 \text { level }(2- \\
\text { tailed). }\end{array}$ \\
\hline $\begin{array}{l}\text { *Implementing Guidelines on the Integration of Ecological Solid Waste } \\
\text { Management under the National Greening Program }\end{array}$ & 4.5574 & .50668 & 0.631 & 0.000 & \\
\hline $\begin{array}{l}\text { *Enactment of the DepEd of Section } 48 \text { Prohibitions of the Republic Act No. } 9003 \\
\text { known as "Ecological Solid Waste Management Act of 2000" }\end{array}$ & 3.9772 & .95049 & 0.232 & 0.000 & $\begin{array}{l}\text { results abo } \\
\text { also depict th }\end{array}$ \\
\hline $\begin{array}{l}\text { *Integration of the schools on curricula waste management concept pursuant to } \\
\text { RA 9512. Entitled "An act to Promote Environmental Education and other } \\
\text { Purposes" }\end{array}$ & 4.4077 & .58278 & 0.727 & 0.000 & $\begin{array}{l}\text { is } \\
\text { str } \\
\text { ciat }\end{array}$ \\
\hline
\end{tabular}

between the level of performance and the level of awareness in terms of Implementing Guidelines on the Integration of Ecological Solid Waste Management under the National Greening Program and the Integration of the schools on curricula waste management concept pursuant to RA 9512 Entitled "An act to Promote Environmental Education and other Purposes but not much with the level of awareness on the Enactment of the DepEd of Section 48 Prohibitions of the Republic Act No. 9003 known as "Ecological Solid Waste Management Act of 2000" which can be attributed to the low level of awareness of the Act and which can also be associated to it being not directly incorporated in the school curricula.

Congruent to the results above, Debrah, Vidal, and Dinis (2021) elucidated in their study that awareness, which can be defined as the perception or knowledge of an event, is accepted as the initial step, performing a requisite function in probable behavioral change and successful education, particularly when related to environmental issues. It has been shown that the students' awareness of environmental problems and solutions can be increased through education. For example, several studies have shown a high SWM awareness. However, it is expected that SWM activities on the schools' campus should involve students as a part of their learning process, considering there is a significant difference between awareness and practice. The cited studies confirm the second hypothesis, which states that the lack of teachers' knowledge influences students' SWM knowledge and awareness. The appropriate skills and awareness obtained through the correctly guided environmental study would assist in changing human behavior toward the environment, which is very important in developing countries.

Interestingly, for Pavliukh as cited in Debrah, Vidal, and Dinis (2021), environmental knowledge does not always influence awareness and behavior. As a result, he explained that students must be early motivated to participate in environmental protection activities and plans.

\section{Association between the Level of Performance with the Level of Implementation}

As reflected on the table, all computed p-values are below the 0.05 are below the 0.05 level of significance set for analysis. Hence, the null hypothesis is rejected. This means that there is a significant relationship between the level of performance and the level of implementation in terms of Implementing Guidelines on the Integration of Ecological Solid Waste Management under the National Greening Program, Enactment of the DepEd of Section 48 Prohibitions of the Republic Act No. 9003 known as "Ecological Solid Waste Management Act of 2000" and Integration of the schools on curricula waste management concept pursuant to RA 9512. Entitled "An act to Promote Environmental Education and other Purposes."

Table 12

Correlation analysis between the level of performance and the level of implementation

\begin{tabular}{|c|c|c|c|c|c|}
\hline Variables & Mean & SD & $\overline{\mathbf{R}}$ & Sig. $(2$ - Tailed $)$ & $* *$ Correlation is \\
\hline Level of Performance vs. Level of Implementation & 4.4240 & 61148 & & & \\
\hline $\begin{array}{l}\text { *Implementing Guidelines on the Integration of Ecological Solid Waste Management } \\
\text { under the National Greening Program }\end{array}$ & 4.0810 & .55410 & $0.762^{* *}$ & 0.000 & tailed) \\
\hline $\begin{array}{l}\text { *Enactment of the DepEd of Section } 48 \text { Prohibitions of the Republic Act No. } 9003 \\
\text { known as "Ecological Solid Waste Management Act of 2000" }\end{array}$ & 4.4077 & .82615 & $0.418^{* *}$ & 0.000 & \\
\hline $\begin{array}{l}\text { *Integration of the schools on curricula waste management concept pursuant to RA } \\
\text { 9512. Entitled "An act to Promote Environmental Education and other Purposes" }\end{array}$ & 4.3896 & 61670 & $0.815^{* *}$ & 0.000 & \\
\hline
\end{tabular}

9512. Entitled "An act to Promote Environmental Education and other Purposes"

Furthermore, the results depict that the school stakeholders' level of implementation of the guidelines and regulations relative to ESWMP is moderately to strongly associated with their level of performance in ESWMP-related activities. In other words, when schools increase their level of implementation of the ESWMP guidelines and regulations, it may lead to higher level of performance in ESWMP-related activities.

The aforesaid claim is supported by Debrah, Vidal, and Dinis (2021) who revealed in their review that the lack of environmental education in most developing countries is caused by fragilities in practical environmental curricula of teachers to respond to modernday environmental issues for sustainable development and cleaner production $(\mathrm{CP})$. To bridge the knowledge gap between the youth and older people in SWM, environmental sustainability education should be integrated into schools at all levels within developing countries.

In the same reference, Debrah, Vidal, and Dinis (2021) considered the absence of teachers and administrators' support to sustainability as one of the barriers for SWM sustainability implementation in school. According to Herrera et al. (2015) and Mcintosh et al. (2014), sustainability cannot fully be implemented in schools and institutions unless administrators and teachers work hard to promote it. Due to the lack of specialized teachers for effective teaching of sustainability in the developing countries, the practice of SWM sustainability leading to cleaner production, will be delayed. The logistical barrier also affects the implementation of SWM sustainability in school. Most schools in developing countries do not have access to any tools and materials, such as data tracking systems, bin sorters, and other items necessary to improve an effective SWM.

Success Stories Showcasing the Best Practices/Initiatives of the Public Elementary Schools in the Implementation of ESWMP This publication is licensed under Creative Commons Attribution CC BY. 
Since the ESWMP practice is not new anymore among the schools in Agusan del Norte division, there have been several success stories which emerged during the interview and triangulation which are part of the data gathering techniques employed in this study.

The success stories were consolidated and summarized into five (5). They include conduct of school ESWMP-related initiatives, partnership and linkage between the school and Local Government Unit, creation of ESWMP implementation plans and school Technical Working Group, incorporation of waste materials in the educative process, and strong participation to division level activities and contests.

The highlight among the five (5) identified success stories was the conduct of school ESWMP-related initiatives. The ESWMPrelated activities in particular were the Brigada Pahina Program by which the government agencies adopt a school for a cleaning program. Some schools made use of recycled plastics in the beautification of the premises and even in their gardening. Notable of the schools'-initiated projects were "Basura Mo, Tago Mo" and "Modyul na, Tanim Pa". "Modyul na. Tanim Pa" is very timely during this pandemic because aside from getting modules, students also had seeds to be planted in their home garden.

\section{Challenges Encountered by the Public Elementary Schools in the Implementation of ESWMP}

As found in the study, there are four (4) challenges identified during the interview and triangulation. They are as follows: (1) poor attitude towards proper waste disposal, (2) "ningas cogon" practice, (3) lack of coordination between schools and partner agencies induced by COVID -19 IATF restrictions, and (4) lack of financial support.

\section{Conclusions}

The stakeholders' level of awareness on ecological solid waste management program in terms of implementing guidelines on the integration of ESWMP under the National Greening Program is in a very respectable level. The stakeholders are familiar with the prohibitions under RA 9003. However, they are not in full cognizant of the prohibition on open dumping, burying of biodegradable, or non-biodegradable materials in flood-prone areas. This situation may be due to the lack of information dissemination about this activity of the LGU itself, as well as DepEd for the dearth of initiatives on information dissemination. Thus, it is high time that schools should strengthen their information dissemination preferably soon after the CoVid-19 pandemic is over.

Also, the stakeholders are very well-informed of the appointment of school representative to the Barangay ESWM Board. Mostly, school representatives to this Barangay ESWM Board are the school principals or their School ESWM Coordinators. Unfortunately, there is less emphasis given to initiative such as the promotion of a "trash-free" baon in schools which is due to the unavailability of such items at home.

In terms of the level of implementation of ESWMP in schools, it is done extensively which also goes to show that the program is indeed functioning well. The schools truly integrated the Solid Waste Management Program under the National Greening Program in their curriculum through the curricular and co-curricular activities that they have undertaken. However, the results also imply that less emphasis was given on the curricula integration as mandated under RA 9512. This is attributed to the selection of the most essential learning competencies as a response of DepEd to address the challenges posed by the pandemic. The MELCs focuses instruction to the most essential and indispensable competencies that the learners must acquire. Thus, the competencies that are relative to NGP are not much highlighted at this present situation. Moreover, the schools implemented the prohibitions on ESWM under Section 48 of RA 9003 extensively and the school ESWM program is functioning well which implies that the stakeholders believe that the schools indeed had implemented the ESWM program and that they had observed well and adhered to the prohibitions of the mentioned Act and they had integrated the waste management concept to the schools' curricula pursuant to the Act.

For the level of performance of schools of ESWMP-related activities, the schools had done such particularly on the environment-related aspects of school policy and the ESWM school operations and presence of environmental programs four (4) to five (5) times in the last five (5) years or almost yearly or annually but thrice in the last five (5) years in terms of partnership and linkages in environmental programs and projects. Moreover, results of the correlation analysis reveal that there is significant relationship between the level of performance and the level of implementation in terms of Implementing Guidelines on the Integration of Ecological Solid Waste Management under the National Greening Program, Enactment of the DepEd of Section 48 Prohibitions of the Republic Act No. 9003 known as "Ecological Solid Waste Management Act of 2000" and Integration of the schools on curricula waste management concept pursuant to RA 9512. Entitled "An act to Promote Environmental Education and other Purposes."

\section{References}

British Plastics Federation (2021). Name of the Article. Retrieved from https://www.bpf. co.uk/sdgs/cities-and-communities.aspx

Cabaniss, A.D. (2014) Message Matters: Application of the Theory of Planned

Behavior to Increase HouseCanahold Hazar ease Household Hazardous Waste Program Participation. https://aura.antioch.edu/cgi/viewcontent.cgi? article $=1163 \&$ context $=$ etds

Debrah, J.K.; Vidal, D.G.; Dinis, M.A.P. (2021). Raising Awareness on Solid Waste Management through Formal Education for Sustainability: A Developing Countries Evidence Review. Recycling 2021, 6, 6. https://doi.org/10.3390/ recycling6010006

DENR, Calabarzon (2019). A Solid Waste Management Success Story. https://calabarzon.denr.gov.ph/index.php/news-events/press-releases/1307-a-solid-wastemanagement-success-story

DepEd Memo No. 24, s. 2019. (2019, February.) 2019 National Search for Sustainable and Eco-friendly Schools. https://www.deped.gov.ph/2019 /02/26/february-262019-dm-024-s-2019-2019-national-search-for-sustainable-and-eco-friendly-schools/

DepEd Memo No. 58, s. 2011. (2011, March). Creation of a Task Force on National Greening Program https://www.deped.gov.ph/2011/03/11/march-11-2011-dm-58-s2011-creation-of-a-task-force-on-national-greening-program/

DepEd Order NO. 5, s. 2014(2014, February) - Implementing Guidelines on the Integration of Gulayan sa Paaralan, Solid Waste Management and Tree Planting under the National Greening Program (NGP). https://www.deped.gov.ph/2014/02/07/do-5-s-2014-implementing-guidelines-on-the-integration-of-gulayan-sapaaralan-solid-waste-management-and-tree-planting-under-the-national-greening-program-ngp/

DENR (2019). Enhanced national greening program. https://www.denr.gov. ph/index.php/priority-programs/national-greening-program

Herrera, J.; Yolanda, M.; Cejas, C.; Larr, M.; Javier, F.; Pe, A. (2015). An approach to the implementation of sustainability practices in Spanish universities. J. Clean. Prod. 106, 34-44.

Ifegbesan, A.P.; Ogunyemi, B.; Rampedi, I.T. (2017). Students' attitudes to solid waste management in a Nigerian university: Implications for campus-based sustainability education. Int. J. Sustain. High. Educ., 18, 1244-1262.

Ikhlayel, M. (2018). Development of management systems for sustainable municipal solid waste in developing countries: A systematic life cycle thinking approach. J. Clean. Prod., 180, 571-586

Licy, C.D.; Vivek, R.; Saritha, K.; Anies, T.K.; Josphina, C.T. (2013). Awareness, Attitude and Practice of School Students towards Household Waste Management. J. Environ. 2, 147-150

Nelson, J. (2017). Partnerships for Sustainable Development: Collective action by business, governments and civil society to achieve scale and transform markets. http://s3.amazonaws.com/aws-bsdc/PartnershipsforSD.pdf

Official Gazette (2001). Republic Act No. 9003. https://www.officialgazette.gov.ph/2001/01/26/republic-act-no-9003-s-2001/ 
ISSN 2250-3153

Paghasian, M. (2017). Awareness and Practices on Solid Waste Management among College Students in Mindanao State University Maigo School of Arts and Trades . file:///C:/Users/CEd_IGF2020_NL2/Downloads/25883492.pdf

Parocha, M.A. Esguerra, Jr, E. \& Hular, C.G. (2015). Solid Waste Management Program: The Grade School Experience. https://ejournals.ph/article.php?id=10671

Permaul, P. \& Phipatanakul, W. (2018). School Environmental Intervention Programs, The Journal of Allergy and Clinical Immunology: In Practice, Volume 6, Issue 1.Pages 22-29, ISSN 2213-2198, https://doi.org/10.1016/j.jaip.2017.10.002.

Phan Hoang, T.T.; Kato, T. (2016). Measuring the effect of environmental education for sustainable development at elementary schools: A case study in Da Nang city, Vietnam. Sustain. Environ. Res., 26, 274-286.

Phan Hoang, T.T.; Kato, T. (2013). Measuring the effect of environmental education for sustainable development at elementary schools: A case study in Da Nang city, Vietnam. Sustain. Environ. Res. 26, 274-286.

Public Linkage, Dialogue, and Education Task Force (PLTF) (1997). From Classroom to Community and Beyond: Educating for a Sustainable Future: Report of the Public Linkage, Dialogue, and Education Task Force of the President's Council on Sustainable Development

Republic Act No. 8749. (1999). Philippine Clean Air Act of 1999. https://emb.gov.ph/wp-content/uploads/2015/09/RA-8749.pdf

Republic Act No. 9003. (2001). Ecological Solid Waste Management Act of 2000. https://www.lawphil.net/statutes/repacts/ra2001/ra_9003_2001.html

Republic Act No. 9512. (2008). Environmental Awareness and Education Act of 2008. https://www.officialgazette.gov.ph/2008/12/12/republic-act-no-9512/

Saxena, J., Vandana, B., \&Singh, J. (2018). The importance of waste management to environmental sanitation: a review. DOI: 10.15515/abr.0976-4585.9.2.202207

Solid Waste Management Manual (2005). https://ec.europa.eu/echo/files /evaluation /watsan2005/annex_files/WEDC/es/ES07CD.pdf

Solid Waste Management in Schools. (2007). http://www.gcpcenvis.nic.in/Kids-Student/Solid_Waste_Management_in_Schools.pdf

Strydom, W.F. (2018). Applying the Theory of Planned Behavior to Recycling Behavior in South Africa. file://CC:/Users/CEd_IGF2020_NL2/Downloads/recycling-0300043.pdf

The Official Gazette (2012). Republic Act No. 9512, an Act to Promote Environmental Awareness through Environmental Education and for Other Purposes. https://www.officialgazette.gov.ph/2008/12/12 /republic-act-no-9512/

Twumasi, K (2017). Awareness and Practice of Solid Waste Management. Eur. J. Earth Environ.

United States Environmental Protection Agency (2021). About the State School Environmental Health Guidelines: EPA's Role in Promoting K-12 School Environmental Health Programs for States. https://www.epa.gov/schools/about-state-school-environmental-health-guidelines\#costs

Varoglu, L.; Temel, S.; Yilmaz, A. (2018). Knowledge, attitudes and behaviours towards the environmental issues: Case of Northern Cyprus. Eurasia J. Math. Sci. Technol. Educ 